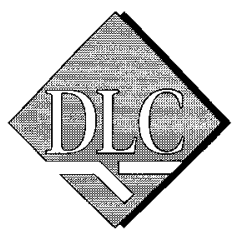

\title{
The Palaeoproterozoic Nagssugtoqidian orogen in West Greenland: current status of work by the Danish Lithosphere Centre
}

\author{
Jeroen van Gool, Mogens Marker, Flemming Mengel and field party
}

The Danish Lithosphere Centre (DLC) has now completed its second season of field work in the Nagssugtoqidian orogen of West Greenland. The work is aimed at studying the orogenic evolution of the Nagssugtoqidian orogen and comparisons with other Early Proterozoic orogens on the northern margin of the North Atlantic Archaean craton (see Larsen, this report). This paper presents the preliminary results from the field work and the current status of laboratory work related to this project.

In the period from 26 June to 25 August, 1995, field work was carried out in an area between latitudes $65^{\circ} 15^{\prime} \mathrm{N}$ (Maniitsoq) and $68^{\circ} 10^{\prime} \mathrm{N}$ (Ataneq and Arfersiorfik fjords) in West Greenland, covering a large portion of the Nagssugtoqidian orogen and part of its southern foreland (Fig. 1). Twenty scientists were involved in the field work, including nine from DLC, six external research partners and five M.Sc. students. In addition, seven other external partners are associated with the project through previous field work or ongoing laboratory studies (see Appendix).

The first field season in 1994 was aimed mainly at obtaining an overview of the different lithological and tectonic elements of the orogen, whereas the second summer was focused more on specific key areas and problems. Several of the sub-projects that were initiated in 1994 were continued. The main research themes of the 1995 field season were, from south to north:

- Configuration of the southern Archaean foreland.

- Structure, metamorphism and petrology of Kangâmiut dykes and their host rocks in the southern foreland and the orogenic margin.

- Structural and metamorphic development of the southern Nagssugtoqidian front.

- The structural development of the boundary zone between the southern and central segment of the Nagssugtoqidian orogen ('Ikertôq thrust zone').

- The Palaeoproterozoic Sisimiut charnockite complex, field relations, petrology and tectonic setting.

- Structure and lithology of the central segment of the orogen.

- The structure and metamorphism of the Nordre Strømfjord - Arfersiorfik flat belt and the nature of the boundary zone between the Archaean and the Palaeoproterozoic complexes.
Several laboratory studies associated with these field projects are currently being carried out on samples collected during the two field seasons. These include geochronology, geochemistry including isotope geochemistry, geothermobarometry and microstructural analyses.

\section{The Nagssugtoqidian orogen}

The 1994 field season resulted in a new subdivision and a re-evaluation of structural elements in the orogen (Marker et al., 1995). Field work was concentrated on outlining the main lithotectonic units and a supporting reconnaissance age dating programme was carried out (Kalsbeek \& Nutman, in press).

Based on lithological, structural, metamorphic, geochronological, geochemical and geophysical features, the Nagssugtoqidian orogen of West Greenland can be subdivided into three ENE-WSW striking lithotectonic segments, which are bounded to the north and the south by Archaean blocks (Fig. 1).

The southern autochthonous foreland consists of a complex of Early to Late Archaean banded gneisses, granitoid intrusives and supracrustal rocks, all predominantly at granulite facies. These are intruded by the Kangâmiut dyke swarm of which one dyke has been dated at $2046 \pm 8 \mathrm{Ma}$ (U-Pb zircon SHRIMP data, F. Kalsbeek, A. P. Nutman and D. Bridgwater, unpublished data, 1995). North of the southern Nagssugtoqidian front (Fig. 1; Escher et al., 1975), these gneisses are variably reworked at amphibolite facies in the parautochthonous southern Nagssugtoqidian orogen.

The 'Ikertôq thrust zone' (Grocott, 1977; see Fig. 1) is a zone of increased strain which forms the boundary between the southern and central Nagssugtoqidian orogen. It is a significant lithotectonic break, since it marks the northern limit of the Kangâmiut dyke swarm and the southern limit of extensive Proterozoic intrusives. The central Nagssugtoqidian orogen can be subdivided into a southern 'steep belt' at granulite facies and a northern 'flat belt' at granulite facies in the west and amphibolite facies in the east. The metamorphism in this part of the orogen has been dated at c. $1850 \mathrm{Ma}$ (Kalsbeek \& Nutman, in press; J. Connelly, unpublished data, 1995) The transition from flat to steep belt broadly coincides with a zone of supracrustal rocks, which are most voluminous at Nordre 


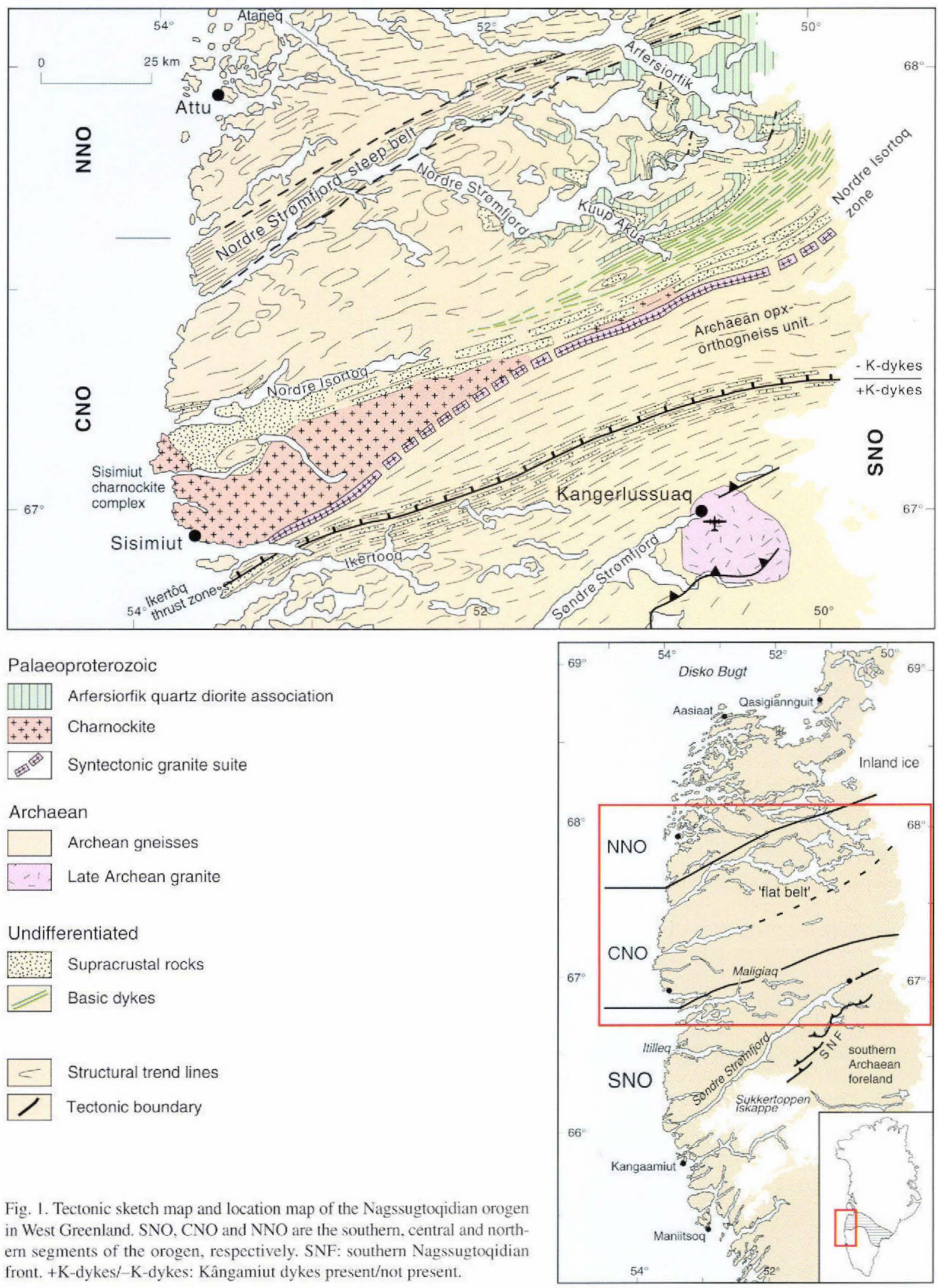




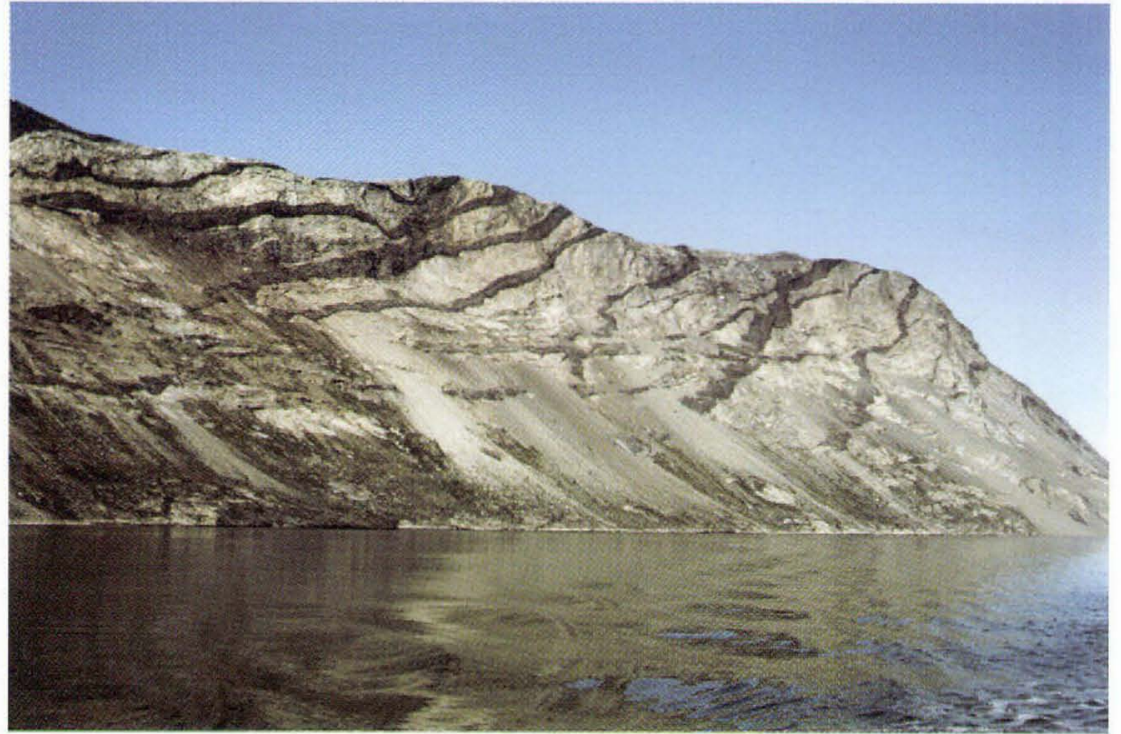

Fig. 2. Kangâmiut dykes in the central part of Søndre Strømfjord. The dykes are transposed to NNW-dipping orientations, but angular discordances and variations in thickness are preserved. Height of cliff c. $500 \mathrm{~m}$.
Isortoq (Fig. 1). The south-western part of the central Nagssugtoqidian orogen is characterised by orthopyroxene-bearing gneisses of the Sisimiut charnockite complex, which have been dated at c. 1920 Ma (Kalsbeek \& Nutman, in press). The south-eastern part contains gneisses of Archaean age which are similar in appearance to the Sisimiut charnockites. The flat belt in the north is characterised by Archaean basement orthogneisses, which are interleaved with a complex of Proterozoic rocks, including the Arfersiorfik quartz-diorite association (Kalsbeek et al., 1987; Kalsbeek \& Nutman, in press).

The transition from the central to the northern Nagssugtoqidian orogen has been tentatively placed at the Nordre Strømfjord steep belt (Marker et al., 1995), but the nature and the position of the boundary is poorly constrained. The Nordre Stromfjord steep belt is a zone of localised deformation, which contains isolated strands of highly strained rocks (Hanmer et al., submitted manuscript), but does not constitute a crustal scale shear zone as previously assumed (Bak et al., 1975). The northern Nagssugtoqidian orogen is dominated by 2800 to 2700 Ma granitoid gneisses, with only few inclusions of presumed older rocks. They are variably deformed at amphibolite facies grade and contain metasedimentary layers which are folded on a kilometre scale. The ages of deformation and metamorphism are poorly constrained and hence the northern limit of Nagssugtoqidian tectonism is presently not known.

\section{New results}

During the 1995 field season the emphasis was on a number of specific projects, which were carried out by members of the field party in different combinations. The main effort was in the southern and central segment of the
Nagssugtoqidian orogen and its southern foreland. Preliminary results are summarised below from south to north.

\section{Southern Archaean foreland}

The Archaean foreland east of Sukkertoppen Iskappe consists of an Early Archaean (pre-3500 Ma, M. Rosing \& A. P. Nutman, unpublished data, 1995) gneiss complex which is juxtaposed against Late Archaean gneisses ( $c$. $2700 \mathrm{Ma}$ ) along prominent lineaments. The timing and nature of movement along these lineaments is uncertain. A suite of metamorphosed mafic dykes, which are tentatively correlated with the Kangâmiut dyke swarm, cuts the Early Archaean complex, but has not been recognised in the younger gneiss complex. These observations suggest that the two Archaean complexes were juxtaposed subsequent to the intrusion of the dykes. This would require significant Palaeoproterozoic tectonic activity in the southern foreland to the Nagssugtoqidian orogen.

\section{Kangâmiut dykes}

The emplacement of the Kangâmiut dyke swarm at c. $2000 \mathrm{Ma}$, just before the main pulse of Palaeoproterozoic orogenesis, makes it a prime target for studies of Nagssugtoqidian deformation and metamorphism. The dykes were studied and sampled in a section along the coast from Maniitsoq in the southern foreland, to Itilleq fjord within the southern Nagssugtoqidian orogen, for structural, metamorphic, igneous, geochemical and geochronological purposes.

Between Maniitsoq and the mouth of Søndre Strømfjord, far south of the Nagssugtoqidian front, the Kangâmiut dyke swarm is variably affected by deformation and metamorphism. Isolated, wide dykes show foliated centres with 
metamorphic mineral assemblages (garnet-hornblendeplagioclase), while dyke margins and thinner dykes generally show well-preserved igneous textures and minerals. Dykes are broadly NNE-SSW trending and any observed deformation has a component of sinistral shear. Closer to the orogen, within tens of kilometres of the southern front, dyke margins are deformed and metamorphic replacement of igneous minerals occurs throughout the dykes. Within the southern Nagssugtoqidian orogen, the dykes are variably boudinaged, foliated and transposed to gently NW-dipping orientations, parallel with the Palaeoproterozoic gneissic fabric (Fig. 2).

Observations both within and outside the southern segment of the orogen, indicate that several generations of Proterozoic dykes are present. Although the majority of the dykes appear to be broadly contemporaneous, a small number of dykes truncate earlier dykes and structures. This may indicate late- to post-Nagssugtoqidian emplacement, or that many of the supposed Nagssugtoqidian structures are in fact pre-Nagssugtoqidian.

\section{The southern Nagssugtoqidian front}

The inland portion of the southern Nagssugtoqidian front is a sharp boundary separating rocks with penetrative, overall NW-dipping fabrics within the orogen, formed by transposition of older structures at amphibolite facies conditions, from rocks to the south which preserve older gneissosity and Archaean granulite facies metamorphism. In the case of Late Archaean granites which are cut by the front, e.g. in the Søndre Strømfjord Airport/Kangerlussuaq region, the front marks the southern limit of a penetrative fabric. The boundary of the Nagssugtoqidian orogen is best displayed by the state of deformation of the Kangâmiut dykes, as described above (Fig. 2). The front is defined by a left-stepping array of discontinuous, narrow, high-strain zones that show minor oblique-sinistral thrust displacement. The fact that lithologies can be traced across the front indicates that displacement on this structure is limited.

In the coastal region, the Nagssugtoqidian front is a diffuse rather than a sharp boundary, indicated by the progressive reorientation of older structures. The 'Itivdleq shear zone', which was previously assumed to represent the western continuation of the Nagssugtoqidian front, is a steep belt, containing an array of isolated, sinistral high-strain zones, which re-utilise pre-existing Archaean shear zones.

\section{The boundary between the southern and central Nagssugtoqidian orogen}

This boundary is characterised by a steeply dipping straight belt with increased strain compared to the remain- der of the southern segment of the orogen. It was introduced by Grocott (1977) as the 'Ikertôq thrust zone' which accommodated major thrust displacement. Panels of Proterozoic supracrustal rocks (Kalsbeek \& Nutman, in press; D. Scott and D. Bridgwater, unpublished data, 1995) are interleaved with Archaean gneisses (Fig. 3). Detailed mapping indicated that this interleaving is a result of combined thrust stacking and large-scale isoclinal folding. Gneissic banding and sedimentary layering are locally truncated by thrust-like structures and presumed thrust-related folds were observed. The thrust surfaces are not characterised by higher strain, which may suggest that thrusting originated at shallow crustal levels by brittle mechanisms and proceeded while the thrust stack was being buried. During subsequent ductile deformation folds were tightened and re-oriented and thrusts as well as existing foliations were transposed into a steeper orientation.

The metamorphic transition from amphibolite to granulite facies, immediately south of the boundary between the southern and central segment of the orogen, lies within this fold-and-thrust belt, but there are no obvious indications that the location of the boundary is a result of the thrusting (cf. Grocott, 1979). The nature of the boundary with the Sisimiut charnockite complex to the north is enigmatic. Intrusive sheets of the charnockite complex locally appear to truncate imbricated gneisses and supracrustal rocks, which places an important constraint on the timing of sedimentation and thrusting in this area.

\section{Central Nagssugtoqidian orogen}

\section{Sisimiut charnockite complex}

Orthopyroxene-bearing gneisses in the Sisimiut area belong to the Sisimiut charnockite complex in the southwestern part of the central Nagssugtoqidian orogen (Fig. 1) and have been dated at $c .1920 \mathrm{Ma}$ (Kalsbeek \& Nutman, in press). Extensive partial melting of the country rocks, both metapelites and Archaean gneisses, and preliminary geochemical and isotopic data indicate that this is an inhomogeneous intrusive body which has been variably contaminated by its host rocks and is therefore likely to have been emplaced by intrusive, rather than structural mechanisms. Orthopyroxene is interpreted as a primary phase, thus making the intrusive body a charnockite s.s. This Palaeoproterozoic charnockite complex is very similar in age and compositional characteristics to charnockite suites in other North Atlantic Palaeoproterozoic provinces (e.g. Campbell et al., 1995) and thus establishes a firm link between the Nagssugtoqidian orogen and other Palaeoproterozoic belts around the North Atlantic.

The boundaries of the Sisimiut charnockite complex are difficult to constrain, since most of the host rocks are ortho- 


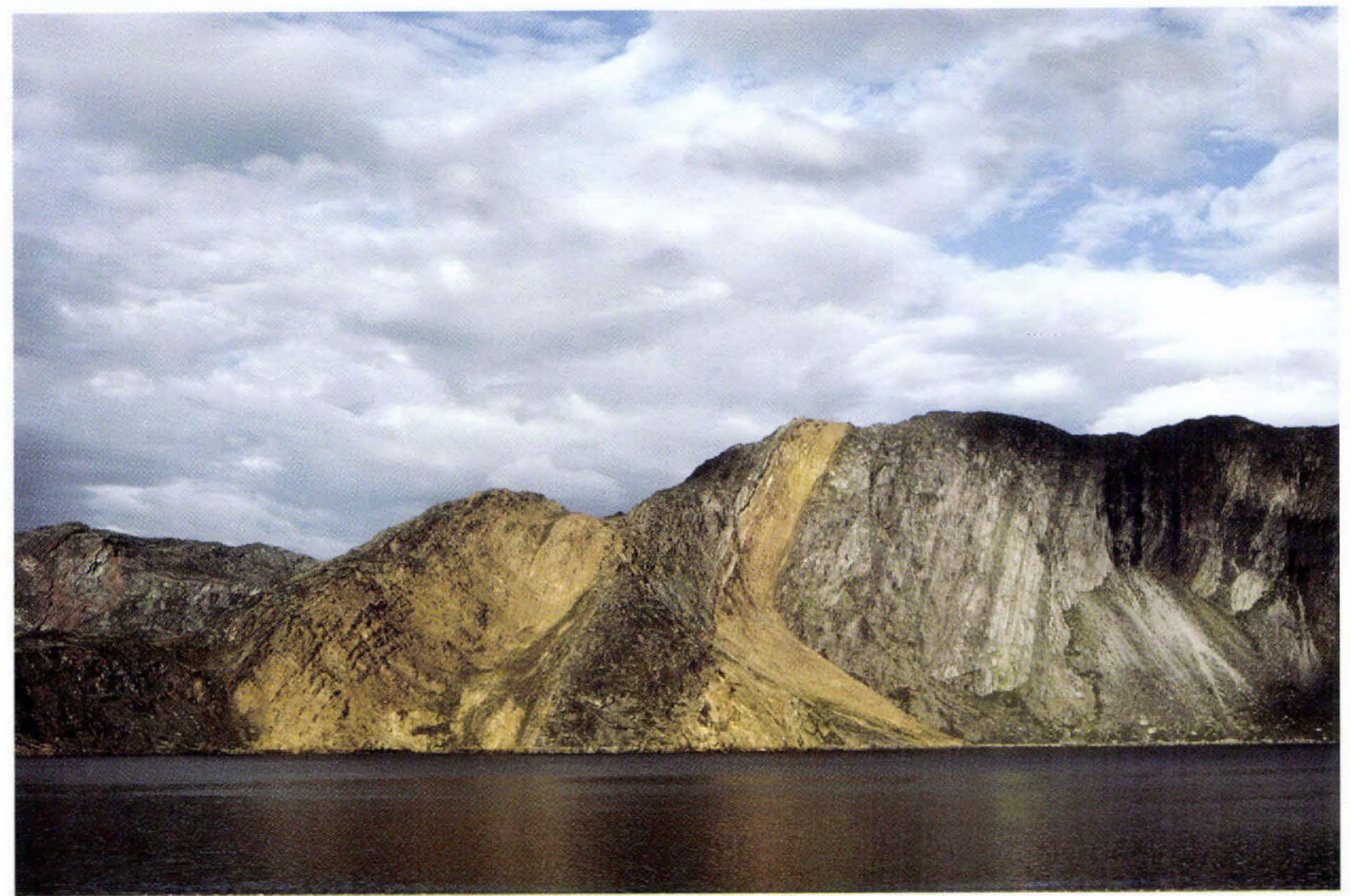

Fig. 3. Panel of Proterozoic supracrustal rocks (buff colour) within Archaean gneisses of the 'Ikertôq thrust zone', Maligiaq. The gneisses are intruded by Kangâmiut dykes. Height of cliff c. $300 \mathrm{~m}$.

pyroxene-bearing gneisses with similar field-appearances, but which yield Archaean ages. To the north the charnockite complex was intruded into a voluminous package of supracrustal rocks, resulting in a diffuse northern boundary. Results of the reconnaissance age dating programme carried out early in 1995 (Kalsbeek \& Nutman, in press) indicated that the charnockites of Proterozoic age are restricted mainly to the western part of the southern Nagssugtoqidian orogen, but thin strands continue far to the east (Fig. 1). Anomalously high $\mathrm{Ba}$ concentrations in stream sediment samples (Steenfelt, 1993) from the south-western part of the central Nagssugtoqidian orogen appear to coincide with known occurrences of the Sisimiut charnockite complex and may aid in defining the regional extent of the body. This will be tested by analyses of samples collected in 1995 from the presumed eastern boundary zone of the charnockite complex.

\section{Nordre Isortoq zone}

Substantial amounts of mainly psammitic and pelitic metasediments occur around Nordre Isortoq (Fig. 1). These form a wedge between the 'flat belt' to the north and the
Sisimiut charnockite complex to the south and thus outline the Nordre Isortoq zone, which is characterised by pronounced partial melting of the metasediments. The zone narrows to the east, but can be traced as an up to $4 \mathrm{~km}$ wide belt all the way to the Inland Ice.

A several kilometre wide tract of syn-kinematic granites, which have been dated at $c .1835 \mathrm{Ma}$ (two samples, U-Pb on zircon by SHRIMP, Kalsbeek \& Nutman, in press), transect the southern part of the central Nagssugtoqidian orogen (Fig. 1). In the west the granites are found south of known occurrences of the c. 1920 Ma old Sisimiut charnockite complex, while the eastern occurrences are slightly south of the supracrustal rocks of the Nordre Isortoq zone (Fig. 1).

Zircons from samples of the metasediments in the Nordre Isortoq zone are of Archaean age (Kalsbeek \& Nutman, in press). It is currently assumed that the sediments were derived from an Archaean continent and deposited on a continental margin. These sediments contrast strongly in provenance, volume, setting and composition from those of the northern part of the central Nagssugtoqidian orogen, which predominantly contain Palaeoproterozoic zircons and are interpreted as deposited in an island arc environment. 


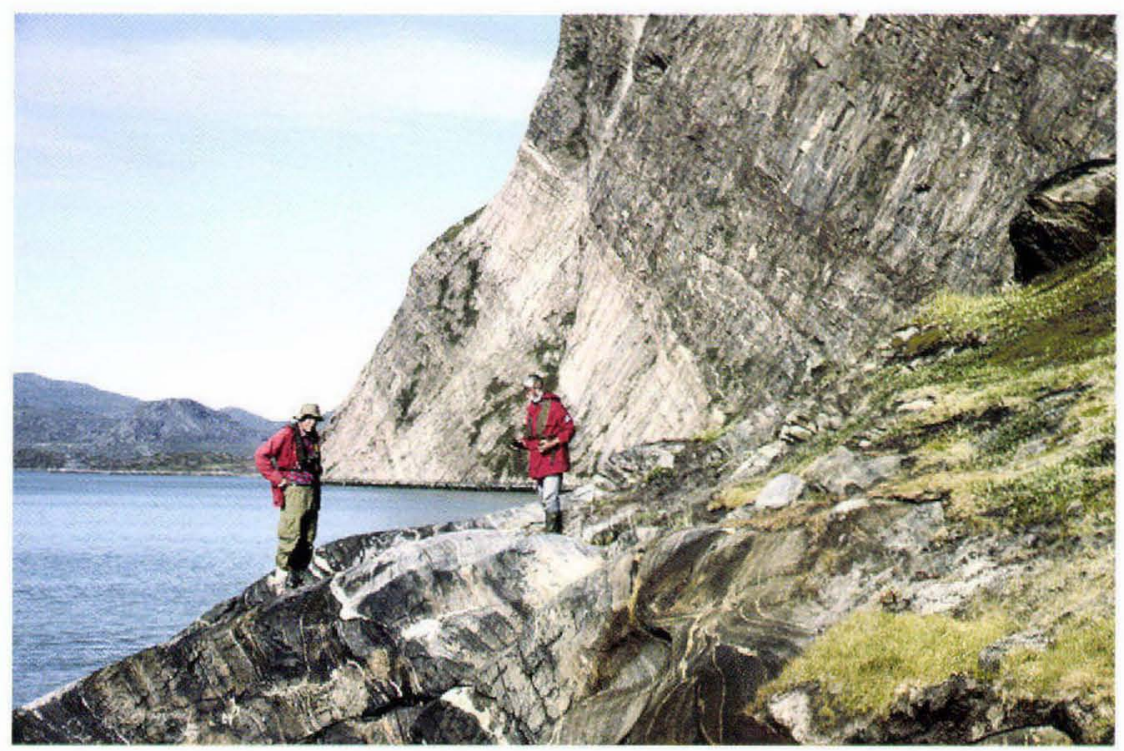

Fig. 4. Rock face at Kuup Akua exposing the contact between pale Archaean tonalitic gneisses underneath dark dioritic gneisses and supracrustal rocks of Proterozoic age. Thin slices of marble and calc-silicates occur at the contact and within the Archaean gneisses. Height of section c. $350 \mathrm{~m}$ high.

\section{Eastern Nordre Stromfjord region}

The 'flat belt' at the eastern end of Nordre Strømfjord has a lower metamorphic grade and is less intensely deformed than the remainder of the central segment of the orogen, and structures related to the early stages of Nagssugtoqidian orogeny are better preserved. Previous field observations, combined with results from the reconnaissance dating programme, suggested the presence of a thrust system which emplaced Proterozoic quartz-diorites on top of Archaean tonalitic gneisses often separated by supracrustal rocks (Fig. 4; Kalsbeek \& Nutman, in press). The area was revisited to test this hypothesis by geometric and structural analysis of the Archaean and Proterozoic rocks, and to collect samples for further geochemical, geochronological and metamorphic studies.

The field work showed that Archaean gneisses are interleaved with a complex of Proterozoic intrusive and supracrustal rocks, including marble, pelite, semi-pelite and volcaniclastic rocks, as well as ultramafic (peridotitic) rocks. Contacts between the Archaean and Proterozoic units are often highly strained, suggesting that they were juxtaposed by thrusting, but large scale isoclinal recumbent folds were also found suggesting that fold nappes may exist. The Archaean gneisses did not form a stable basement upon which the Proterozoic gneisses were emplaced, but were intimately involved in the thrusting event. Kinematic indicators suggest predominantly top-to-the-east transport, but it is not certain whether this kinematic framework is related to the emplacement of the thrust sheets or represents a later event. The rocks in the northern part of the central Nagssugtoqidian orogen were folded into complex domeand-basin interference patterns, while the enveloping surfaces of the thrust sheets remained sub-horizontal.

\section{Supporting projects}

All field projects in the Nagssugtoqidian orogen are supported by laboratory work, including geochemical, geochronological, metamorphic and microstructural studies. A few of the laboratory studies are of a regional reconnaissance nature, but most highlight detailed aspects of the geology of the orogen. Some of the more specific projects include:

- Timing of igneous, metamorphic and structural events as well as provenance studies of metasediments. This is carried out by U-Pb dating (SHRIMP, TIMS and Laser Ablation Microprobe ICP-MS) of zircon, sphene, rutile and monazite, and by $\mathrm{Ar}-\mathrm{Ar}$ dating of hornblende.

- Metamorphic studies, aimed at the reconstruction of $P-T$ paths for different tectonic elements in the orogen, and correlation of these with structural observations and radiometric age determinations.

- Geochemical and isotope studies aimed at determining the sources, emplacement processes and tectonic settings of Proterozoic intrusive rock suites in the orogen.

- Microstructural analyses of samples from key tectonic zones in the orogen in order to determine strain paths, deformation mechanisms and kinematics of selected rocks and to constrain the relative timing of deformation with respect to metamorphism.

\section{Conclusions}

Through a multidisciplinary approach, the two field seasons and the associated laboratory work have led to a much better understanding of the tectonic evolution of the Nagssugtoqidian orogen. Several elements typical of modern colli- 
sional orogens have been recognised in the Nagssugtoqidian orogen, including syn-orogenic sedimentary sequences, island arc intrusives and supracrustal rocks, peridotitic ultramafic rocks, imbricate thrust stacks, high grade metamorphism as a result of crustal thickening and large Proterozoic intrusive bodies. Speculations as to the collisional nature of the orogen (e.g. Bridgwater et al., 1973), can now be more firmly postulated. The observations all support the interpretation that the Nagssugtoqidian orogen displays a deep crustal section through the locus of collision of two Archaean crustal blocks during the Palaeoproterozoic.

Further field work is planned for the 1997 season, when work will focus on the central and northern segments of the orogen. Particular targets include the Nordre Isortoq suite of metasediments and their relationships to the Sisimiut charnockitic complex in the south and the gneisses to the north. The transition from the central to the northern segment of the orogen across the Nordre Strømfjord steep belt will be further investigated. In addition, future research projects are expected to emerge as field data are compiled and interpreted and as results of ongoing laboratory work become available.

Acknowledgements. Anders, Ellen, Peter and Michael Pedersen of $M / S$ Kissavik are thanked for providing excellent logistic services. We thank Lene Frøsig and Jørn Hodal for helping with practical arrangements in Sisimiut. We also acknowledge the help of Håkon Kristensen and Jens Larsen, helicopter pilots from Grønlandsfly A/S, who went beyond the call of duty to ensure a successful field season.

Geochronological analyses by SHRIMP were funded by DLC, with additional support from the Geological Survey of Denmark and Greenland (GEUS), the Danish Research Councils (grant to D. Bridgwater) and the Schuurman funds (grant to F. Kalsbeek). David Scott provided LAM ICP-MS analyses of selected metasediment samples.

\section{Appendix:}

The 1995 field party in the Nagssugtoqidian orogen:

G. Manatschal, M. Marker, F. Mengel and J. van Gool (DLC), D. Bridgwater, B. Hageskov and M. Rosing (University of Copenhagen and DLC), L. Løfqvist, H. E. Olsen, D. Ulfbeck and L. Wichmann (University of Copenhagen), F. Kalsbeek and A. Steenfelt (GEUS and DLC), P. S. Jensen (University of Aarhus, Denmark), B. den Brok and C. Passchier-(Johannes Gutenberg University, Mainz, Germany), L. Campbell (University of Colorado,
Boulder, USA), J. Connelly (University of Texas, Austin, USA), K. Mayborn (University of California, Davis, USA) and B. Willigers (Vrije Universiteit Amsterdam, The Netherlands).

External research partners: A. Cadman (Leicester University, UK), S. Hanmer and D. Scott (Geological Survey of Canada, Ottawa, Canada), L. Kriegsman (University of New South Wales, Sydney, Australia), G. Nichols (Maquarie University, New South Wales, Australia), A. P. Nutman (Australian National University, Canberra, Australia) and M. Whitehouse (University of Oxford, UK).

\section{References}

Bridgwater, D., Escher, A. \& Watterson, J. 1973: Tectonic displacements and thermal activity in two contrasting Proterozoic mobile belts from Greenland. Phil. Trans. R. Soc. Lond. A. 273, 513-533.

Campbell, L. M., Bridgwater, D. \& Farmer, G. L. 1995: A comparison of Proterozoic crustal formation along the Torngat Nagssugtoqidian - Lapland collision belts: preliminary constraints from $\mathrm{Nd}$ and $\mathrm{Pb}$ studies in northern Labrador. Lithoprobe Rep. 45, 22-36.

Escher, A., Escher, J. C. \& Watterson, J. 1975: The reorientation of the Kangâmiut dyke swarm, West Greenland. Can. J. Earth Sci. 12, 158-173.

Grocott, J. 1977: The northern boundary of the Ikertôq shear belt, West Greenland. Unpublished Ph.D. thesis. Univ. Liverpool, 179 pp.

Grocott, J. 1979: Controls of metamorphic grade in shear belts. Rapp. Grønlands geol. Unders. 89, 47-62.

Hanmer, S., Mengel, F., Connelly, J. \& van Gool, J. submitted MS: Significance of crustal-scale shear zones and mafic dykes in the Nagssugtoqidian orogen, SW Greenland: a re-examination. Submitted to J. Struct. Geol.

Kalsbeek, F. \& Nutman, A. P. in press: Anatomy of the Early Proterozoic Nagssugtoqidian orogen, West Greenland, explored by reconnaissance SHRIMP U-Pb dating. Geology.

Kalsbeek, F., Pidgeon, R. T. \& Taylor, P. N. 1987: Nagssugtoqidian mobile belt of West Greenland: cryptic 1850 Ma suture between two Archaean continents - chemical and isotopic evidence. Earth Planet. Sci. Lett. 85, 365-385.

Marker, M., Mengel, F., van Gool, J. \& field party 1995: Evolution of the Palaeoproterozoic Nagssugtoqidian orogen: DLC investigations in West Greenland. Rapp. Grønlands. geol. Unders. 165, 100-105.

Steenfelt, A. 1993: Geochemical mapping - progress in Greenland. J. Geochem. Explor. 49, p. 5-13.

J. V. G., M. M. \& F. M., Danish Lithosphere Centre, Copenhagen 